\title{
Alienation and Emotion: Hegel Versus Sentimentalism and Romanticism
}

\author{
Warren D. TenHouten ${ }^{1}$ \\ ${ }^{1}$ Department of Sociology, University of California, Los Angeles, CA, USA \\ Correspondence: Warren D. TenHouten, Department of Sociology, 264 Haines Hall, UCLA, 405 Hilgard Avenue, Los \\ Angeles, CA 90095-1551, USA. E-mail: wtenhout@g.ucla.edu
}

\author{
Received: May 6, 2019 Accepted: May 31, 2019 Online Published: June 18, 2019 \\ doi:10.5539/res.v11n3p1 URL: https://doi.org/10.5539/res.v11n3p1
}

\begin{abstract}
The structuralist and social-psychological perspectives on alienation are described, with attention to Seeman's contention that the experience of alienation is based more on sentiment than on reason. The passions in early modernity are described, and the eighteenth-century moral sentimentalists Hume, Smith, and Kant are discussed. Romanticism is described as the first self-critique of modernity, as it opposed Enlightenment science, rationalism, and uniformitarianism; it is linked to interiorized emotionality and to diversitarianism. Romantic concepts of alienation include inhibition of natural sexuality, oppressive condition of work, and the loss of an imagined Golden Age before human alienation. Hegel's Phenomenology outlines a four-stage model of the undoing of social domination which has a narrative structure consistent with romantic story-telling, but was grounded not in romanticism but in Gnosticism and Lutheran dialectics. Hegel's critique of sentimentalism and romanticism is explored, with Hegel emerging as a dedicated anti-romantic who condemned the sophistry of Schlegel and Novalis's 'beautiful soul', arguing that the self, to be viable, cannot remain encapsulated in inner subjectivity but must rather engage in emotion-laden confrontation with self-willed others in the social world; this requires a positive kind of alienation of the self from itself. Romantic effort to keep the self in itself as protection from the corrupted and corrupting social world was misguided. Hegel was right in asserting that the self is necessarily both subjective and objective, both inner and outer, but wrong in his contention that the self can progress by resolving inner contradictions, for the self, as the core of our personality, rather progresses through incorporating and elaborating contradictions, ambiguities, and polysemantic meanings.
\end{abstract}

Keywords: alienation, dialectics, emotion, Hegel, passion, rationality, romanticism, self, self-estrangement, sentimentalism

\section{Introduction: The Subjective Experience of Alienation}

Long contested, the companion terms 'alienation' and 'estrangement' have taken on varied meanings, reflecting differing assumptions and epistemological, ontological, and sociological frames of reference. Social philosophers and theologians have examined their ethical, normative, and existential dimensions, while social scientists have focused on their objective, structural determinants within specific historical conjunctures, and as a subjective experience of the individual. A consensus nonetheless holds that alienation-estrangement implies relinquishing, distancing from, separating from, or becoming a stranger to, significant others, sociocultural norms and values, work, school, family, nature, one's self, and beyond. Following Seeman's (1959) landmark article, "On the Meaning of Alienation," alienation research intensified from 1965-1978 (peaking in 1969), after which it gradually contracted, then levelled off (TenHouten, 2017a, p. 52) as political and economic developments brought new issues to the fore. But alienation of all kinds persists, and research on alienation remains as important as ever. The contemporary literature on alienation encompasses two broad approaches.

The objective, etiological, and largely Marxian perspective investigates the sociohistorical circumstances and structural conditions that engender or constitute alienation. In this view, "alienation consists of the structural, organizational, and exchange relations that diminish human capacities in work and elsewhere," so that alienation is "an objective fact independent of individual sentiments" (as described, but not endorsed, by Seeman, 1991, p. 19). In this view, the alienated individual's feelings, perceptions, cognitions, and intentions are of no interest, as the concept of alienation "does not assume that the alienated are aware of their condition.... The roots of alienation are not in...intrapsychic processes but in the societal and political structures" (Etzioni, 1968, p. 618).

The alternative, subjectivist, social-psychological perspective on alienation, adumbrated by Rousseau (1762a, 1762b, 1781; see also S. Campbell, 2012, chap. 5), proposes that alienation consists of inner mental states, even if its determinants lie outside the individual, in socio-environmental relations. Seeman (1991) emphasizes the importance of defining alienation "in terms of subjective sentiments," while taking into account the "structural circumstances that 
generate such sentiments, condition their interpretation, or influence their behavioral consequences," so that "[a]lienation is thus a subjective state of an individual, to be distinguished sharply from alienating social structures" (p. 21). Seeman's work had been grounded in behaviorism, but he transcended its limitations by proposing to look into the 'black box' of the individual's mind, where the experience of alienation is found, as cognition and as affect, sentiment, and passion. Alienation, Seeman (1991) argues, is primarily a matter of sentiment, and it can be seen as involving affect more than reason: An individual can think about being separated from his community, as an objective fact, without being alienated; it is only when he or she also feels this separation, perhaps as a state of loneliness, or even of despair, that alienation occurs (TenHouten, 2017a, chap. 7).

This paper examines relationships between alienation and the emotions as they were historically understood in modern Western philosophy and social theory. We begin with a few definitions. Emotions have been defined in innumerable ways, and can be seen as functioning to establish, maintain, or disrupt relations in the social environment; they are characterized by an adaptive action-readiness to deal with challenging situations. An emotion is a reaction to a social event, and therefore is 'outside' of an individual's full control, existing as "a behavioral storm which is endured rather than an activity which is directed" (C. Campbell, 1987, p. 70). Yet, emotions most certainly are directed toward objective and goals. Emotions range from joy, sadness, anger, and fear to complex emotions such as envy, resentment, hope, and despair. Passions can be defined as strongly experienced, often difficult to control emotions by which the mind is powerfully affected or moved, and which can range from deep love to a blind rage. Sentiments are "socially constructed pattern[s] of sensations, expressive gestures and cultural meanings organized around a relationship to a social object" (Gordon, 1981, p. 566); they are typically focused on a particular person, object, or situation. They include romantic love, parental love, loyalty, patriotism, trust, friendships, and related social orientations. Feelings are difficult to define and have a vast connotation, but include touch and consciousness of all other bodily sensations, including the experience of physical drive states such as hunger, pain, and fatigue.

\section{The Passions in Early Modernity}

Early modern Europeans sought a scientific discourse concerning the emotions, but initially continued to rely on an Ancient Greek psychophysiology, Galenic humoralism. In Galenic four-humor theory a person might be characterized as having a dry wit, or a cold heart, and have a temperament that is sanguine (hot and moist) or melancholic (cold and dry). The humors were fluids whose excess was believed to cause most diseases. With the advent of modernity, this proto-scientific formulation was abandoned, or more accurately, faded away (Temkin, 1973), as its descriptions of passions and temperaments were downgraded to mere metaphors (Paster, 2004; Paster, Rowe \& Floyd-Wilson, 2004).

Interest in the emotions intensified in the seventeenth century, and represented one aspect of a deeper inquiry into in the relationship between knowledge and power. A ruler, it was recognized, must be in control of his own emotions, and to rule effectively must be able to grasp and manipulate the passions and emotions of those around him, "to detect and play on the ambition, envy, fear, or esteem of courtiers, counselors, and citizens" (James, 1997, p. 3). It came to be widely believed that control of the passions (today called 'emotion management') can enable a transformative unleashing of personal efficacy, both for rulers and for the citizenry in everyday life. Consistent with a synthesizing urge in early Western philosophy, scholars including Wright (1601) (who clung to Galenic theory, seeing the passions as inextricably bound up with the humors), Hobbes (1640), Senault (1642), Descartes (1649), Charleton (1674), Malebranche (1674-1675), Spinoza (1677), Locke (1690), Hutcheson (1725), and Hume (1739, 1748) participated in efforts to classify, and tame, the passions. A consensus emerged that reason and emotion, while different categories of the mind, can operate synergistically in productive action. It was recognized that human emotions such as love, pride, gratitude, and ambitiousness, if properly channeled and morally grounded, can contribute to human progress (Crocker, 1963; James, 1997; Frazer, 2010). There was in these times concern about insincerity of emotional expression (Rousseau, 1754, 1762a/1979, pp. 40-41) and a clear awareness that emotions can possess political intentionality.

\section{Moral Sentimentalism}

During the eighteenth century's political revolutions - included the American Revolution (1775-1783), the French Revolution (1789-1799), and the Napoleonic Wars (1799-1815), there developed a crisis of concepts and values, the consensus about which were grounded in the idea of justice and morality generated through reflective freedom and individual autonomy, concepts of that century's intellectual current, the so-called Enlightenment. Within the Enlightenment, rationalism attained dominance, but the Enlightenment also contained numerous varieties of sentimentalism,(note 1) which held that refined feelings of sympathy were a basis of morality. The rationalists and moral-sentimentalists agreed that individuals manifest reflective autonomy in the legislating of moral and political standards, but they were divided on the nature of the self that establishes, and then abides by, these standards. The rationalists sought to discover moral principles on the basis of reason alone, but the sentimentalists also included feeling and imagination, so that reflection became an effort of the mind as a whole. Sentimentalism offered "an empirically 
grounded sociology and psychology of moral and political reflection that focused on the key social-psychological faculty of sympathy, ...by which inner mental states are shared among individuals" (Frazer, 2010, p. 8). Accordingly, moral commitments can be derived from, and justified by, the emotions employed as approving or disapproving of social behavior.(note 2) If our moral sentiments are based on well-founded beliefs, then we can potentially approve or disapprove of our own sentiments, declaring them, on reflection by the mind as a whole, to be moral or immoral. Moral sentiments, to be validated and declared authoritative, must meet criteria of being rational, contributing to human happiness, and reaching a state of reflective equilibrium. Notable early contributions were offered by Shaftesbury (1699-1714), who introduced the notion of a moral sense, and by Hutcheson $(1725,1728)$, whose anti-rationalism posited an innate moral sense wherein approval is based on "the general calm desire of the happiness of others" (Hutcheson, 1728/2004, p. 175). Prominent philosophies of moral sentimentalism were developed by David Hume and Adam Smith, who were close friends but much at odds over the nature of moral sentiments.

\subsection{Hume}

Hume (1739/1978, p. 415) opposed Enlightenment rationalism, arguing that human social behavior is primarily determined not by reason but by emotion.(note 3) He saw morality as based on the sentiment and passion, declaring that "reason is, and ought only to be the slave of the passions." At the same time, Hume recognized that the moral sentiment includes cognitive elements subject to revision upon reflection (Frazer, 2010, chap. 2-3). Our moral evaluations, he argued, are directed not to individual persons but are rather impersonal, directed to the character of generalized others. Our verbal framing of moral judgment, Hume further qualified, might not express our actual 'sentiment' but what we predict we would feel if we made the appropriate corrections by overlooking particularities of the present situation; thus Hume, while emphasizing affect, also provides an indispensable role to thought and judgment (Baier, 1991, pp. 134-135, 179-197).

\subsection{Smith}

In critique of Hume's proto-utilitarian, public-interest oriented theory, Smith's (1759) liberal sentimentalism focused on the individual positioned as an impartial spectator observing and judging behavior. Even in observing those we are most involved with - friends, family members, ourselves, we still feel our moral judgments should be impartial, and will strive to anticipate what would win the approval of an impartial observer. Our passion of sympathy is stimulated not so much by pity for suffering classes, masses, or of humankind as a whole, as it is by actual situations involving concrete individuals. Whereas Hume imagined sympathy as a rudimentary level of 'emotional contagion' wherein we 'catch' an emotional state from another, Smith rather described the imaginative work of sympathetically placing ourselves in the other's situation and working out "What to feel, as though we were they" (Darwall, 1998 p. 264); also, we can perceive that others are placing themselves in our shoes. Such moral judgment does not imply 'mirroring' of others' feelings: For example, if we sense others' pity for our pain, we react not with intensified pain but rather feel comforted and experience gratitude. Thus, sympathizing does not imply simple contagion, 'infection', or sharing of the same feelings or emotions. Sympathy, or projective empathy, can be cognitive challenging if the other is experiencing complex emotions, such as anger together with resentment (Smith 1759/2000, pp. 44-51; TenHouten, 2018), which we are most unlikely to also experience. The target of resentment is apt to experience guilt, remorse, or indifference, but not counter-resentment. Even in cases we are ourselves sympathetically feeling the same emotion as another, we will in all probability be experiencing it at a lower level of intensity. Smith argued that if a spectator intuits an actor's emotional feelings, and these feelings are seen as inappropriate to, or not warranted by, the actual situation, the spectator is not apt to react with "projective empathy" (Darwall, 1998, pp. 267-269) or "sympathy" (Mullan 1988, pp. 18-56).

\subsection{Kant}

Immanuel Kant was influenced by Hume, Smith (his early favorite philosopher), and other moral sentimentalists, and at least through the mid-1760s outlining of his theory of ethics, clearly belonged to the reflective-sentimentalist camp (Frazer, 2010, chap. 5). In his pre-critical period, Kant advocated dedication of oneself to the cultivation of reflectively refined feelings as a pathway to true virtue. If sympathetic feelings no longer serve our practical interests, he argued, these feelings should not be abandoned, for they can lead to the laudable goal of feeling "a tie to all humanity," a kind of feeling that Kant, however, "would later condemn as a passion" (Frazer, 2010, p. 114)

At the midpoint of his life, at about age 40, Kant (1785) rather abruptly abandoned sentimentalism, and excluded sympathy and the emotions from the grounds of morality. However, he never rejected kind-hearted sentiments as such, and he maintained that it is our duty to cultivate sympathetic emotions and to enlist them in service of the will's moral purposes, but on the condition that they are subjected to control and do not overwhelm one's rational agency. Kant defined 'affects' [Affecte] as sympathetic feelings that can overwhelm the will, a kind of emotional agitation that momentarily disables reflection. He defined 'passions' [Leidenschaften] as reflectively refined sentiments self-consciously incorporated into action. But even if they are pursued in a manner consistent with means-ends rationality, passions, both 
positive and negative, Kant saw as evil insofar as they usurp the reason's rightful authority over decision making, or subordinate moral incentives to the incentives of feeling (Frazer, 2010, pp. 113-114). What Kant had done was to abandon the holism of mind of his sentimentalist period in favor of the hegemony of reason.

\section{Romanticism}

\subsection{Romanticism as Critique of Modernity and Reason}

In no small measure as a consequence of Kant's extraordinary centrality to Enlightenment thought, together with remarkable advances in science, mathematics, and technology, the whole eighteenth-century Enlightenment period came to be called 'The Age of Reason'. The exaggerated pride of place accorded to reason and rationality in Enlightenment philosophy and science stimulated an oppositional counter-movement, that of Romanticism (with roots in various sentimentalisms), which gradually emerged in the 1760s and then flowered in the first half of the nineteenth century, a period which came to be called 'The Romantic Era' (e.g., by Murray, 2003, 2004) and 'The Age of Romanticism' (e.g., by Kuhn, 2009). Romanticism persists today, finding a role structuring romantic love; preserving its place in aesthetic expression in literature, art, poetry, and the humanities; in bohemian and New Age lifestyles (Sebald, 1984); in consumerism and advertising, including the consumption of vacations in putatively idyllic island settings (C. Campbell, 1987); in the practice of non-scientific knowledge practices such as the Tarot and the I Ching (TenHouten \& Kaplan, 1972); and in video games, positioned as a heroic warrior destroying enemy soldiers or inhuman invaders (Jeffries, 2007).

In the so-called Age of Reason, it was believed that the world itself is logical, existing in a state of static completeness with a coherent order, as articulated in the principle of sufficient reason, which holds that all that exists must have a reason, cause, or ground. Reason, possessed by all humans, enables the summing up of knowledge in self-evident truths, including the laws of nature, which are accessible to every rational mind able to see the universal as true and the particular as false. Not only science, but even poetry, was to speak a universal language. With this commitment to the universal, European thought (from the late-sixteenth to the late-eighteenth centuries) was devoted to the standardization of thought. This conceptualizations of mind and nature contained a germ of its own opposite, which stimulated a counter-movement, finding expression in Sentimentalism and then in "a conscious and aggressive revolutionary movement in thought, ...Romanticism," which became "the first self-critique of modernity" (Lovejoy, 1936/1965, pp. 288, 296; see also Löwy \& Sayre, 2001, p. 21).

The proto-romantic Sturm and Drang movement in German music and literature, from late-1760s-early-1780s, saw human emancipation not in the Kantian tradition of venerating reason and seeing truth as universal and uniform, but rather in an individualistic celebration of diversity, so that artistic expression led to proliferation of genres and poetic verse-forms, the seeking of local color, and even the grotesque, in a demand for particularity and an antipathy toward standardization. Not reason but emotion came to express freedom and spontaneous agency, wherein the human subject is no longer seen as mechanically related to the physical world but rather as the creator of ideas and works. Feelings and emotions became the vehicles for the fulfillment of life and the attainment of freedom (Pascal, 1953). The romanticists venerated intense emotionality, which became an end in itself, an aspect of the very purpose of life, necessary for any knowledge that could be gained. The romantic imagination found expression in art, literature, and poetry, diversifying its artistic productions "in as many ways as possible" (Formey, 1757, cited in Lovejoy, 1936/1965, p. 294). This profound change in mentality was far wider than Romanticism, as it represented a more general shift from uniformitarianism to diversitarianism.

Romanticism emerged, in part, as an effort to regain a sense of the sacred in the face of the Enlightenment views that only quantifiable material phenomena constitute the real world (Sullivan, 1933), that 'soul' can be reduced to 'mind', and that processes of mind, in turn, are but artifacts of delicate brain mechanisms obeying physical laws. The romanticists rather believed that rational, scientific ontology had undermined human life's emotional character. They celebrated the sublime and the wild in nature (Walzel, 1966; Honour, 1979), and argued that instinct, desire, passion, feeling, emotion, and sentiment propel authentic human experience and action.

The Romanticists were not entirely dismissive of the scientific enterprise. Goethe, for example, had gestured toward exploring the 'elective affinities' of love, sex, and devotion, a key concern of romanticists linked to the fashionable 'science' of the attractiveness ('affinities') of distinct chemicals (Porter, 2001, p. 59). Goethe's romanticism did not seek to overthrow reason per se, but rather held that truth can only be fully apprehended by the non-rational faculties of the mind, by insight, enthusiasm, passion, intuition, originality, and, above all else, imagination (Bowra, 1949; Pyle, 1995). Especially in England and the United States, there developed a "Romantic passion for all things scientific..., bound up with the energies of the time" (Mary Shelly, 1818/2012, p. 491; see also Goodall, 2016). A debate about electricity pitted Galvin, who in 1781 had speculate that electricity is the vital force of life, perhaps life itself, against Volta, who countered that electricity could only stimulate 'dead' muscles into motion. In this period, advances in electricity were seen as a vital medium for the romantic rebellion, as expressed in Mary Shelly's (1818) novel, Frankenstein. Just as Prometheus had 
stolen fire from Mt. Olympus, so also Victor Frankenstein, a modern Prometheus, mastered the creative power of electricity, which was seen as a life force, and even as an alternative to religion, more particularly as an instrument of recovery from the dreary idea of Calvinist predestination (Priestly, 1775; Godwin, 1831).

Modern science in the seventeenth and eighteenth centuries had contributed to the liberation of humanity from theological dogmas based on belief systems free of evidence and reason, animistic superstitions, practices of sorcery and magical divination, and pseudo-sciences such as astrology and alchemy, yet it had also contributed to a world seemingly no longer responsive to human values. The Scientific Revolution triggered "a new sense of human alienation" wherein no "redeeming context" could help explain "the larger issues of human existence" (Tarnas, 1991, p. 326). The Romanticists believed that a disturbing rift had developed between humanity and nature, a disruption of the "great chain of being" (Lovejoy, 1936/1965, chap. 10; see also Wilson, 1980). If the universe really were a gigantic clocklike mechanism designed by 'God', as many early modern philosophers, and especially Deists, believed, once set in motion it would no longer needs its Maker. Moreover, if mechanical laws of nature really governed even human minds, there could be no free will and no ethical responsibilities (Eichner, 1982, p. 12). Thus, the future, especially in Calvinism, Pietism, and Methodism, came to be seen as predestined, a belief that led to the idea of immersion in an occupational calling as a basis for "the releases of emotion based religious anxiety" (Weber, 1904-1905/2002, p. 66).

Romanticism emerged in opposition to Enlightenment confidence in instrumental and scientific rationality, to the Scientific Revolution led by Copernicus, Kepler, Galileo, and Newton; to many aspects of the industrial revolution; to the emergence of a modern capitalistic social order; and to the wrenching shift from rural to urban life, where city life for many involved overcrowding, filth, squalor, and disease, and which stimulated artistic evoking of rural idylls. Romanticism was also reactive to the Cartesian view of human and animal bodies as physical mechanisms. These interrelated developments deposed humanity's place at the center of the universe. The Romanticists saw in these intellectual trends a threat to human spirituality and to the meaning of human life; they were seen not as liberating but rather as sources of disenchantment. The Romanticists believed that mechanization had corrupted the highest imaginative values of humanity, and that people had grown mechanical in head, heart, and hand. Romanticism represented a recrudescence of forces that since the Renaissance had very gradually gained traction. These forces militated against the cold science and administrative technology which prioritized instrumentally rational thought and action, while reducing the importance of value-based rationalities, emotions, sentiments, and passions (Weber, 1904-1905, 1915b; Koch, 2005).

Seeking to rediscover a lost paradise within bourgeois society, romanticists also endeavored to transform their own social environments, forming literary circles with likeminded others, or joining utopian social movements (Saint-Simonianism, transcendentalism, socialism, communism). Some endeavored to form social movements built for two by falling in love (Alberoni, 1983; Weber, 1915a/1972, p. 347), a solution that has become the popularized meaning of 'romanticism' today. Others sought escape from urban bourgeois society by fleeing the city for the countryside, perhaps setting up communes and seeking self-sufficiency.

Rousseau advanced the cause of a radical individualism and sense of potential freedom from oppressive institutions and governments. He appealed to emotional experience, believing that emotion comes from nature, and from the natural facts of sexual love. In addition to his confessions regarding his enjoyable sexual episodes, Rousseau (1765-1770) articulated an objectless yearning, a sentimental nostalgia, which presciently expressed the very essence of the romantic orientation. With his valorization of nature and his distrust of cultural forms that separate men from living naturally and honestly, Rousseau argued that thinking alone cannot not give us the answers we need, for we must naturally feel what is right, as only the intrinsic goodness of our feelings and emotions can protect us from the corrupting influence of oppressive social institutions. Rousseau became an intellectual inspiration for Romanticism; he has been described as the 'father' and the 'high priest' of Romanticism. Rousseau, and the romantics in general, focused not only on the positive 'sentiments of being' such as happiness, love, awe, hope, and bliss, for they were also much concerned with melancholia, dejection, pessimism, humiliation, despondency, sorrow, loneliness, horror, terror, and especially, despair (McGann, 1982).

The Romantics sought the recovery of an idealized Golden Age, wherein humanity had been at peace with itself, that was variously believed to have existed in the primitive stage of human development, in Greek and Roman antiquity, or in the Middle Ages (the age of chivalry, courtly love, and gallant knights in shining armor rescuing maidens in distress). Romanticism, above all else, was motivated by a sense that with the advent of the modern world there had developed a profound sense that something precious had been lost. All of these putative homelands reflect nostalgia for a lost unity of being (Skempton, 2010, pp. 31-33).

The homelessness and loneliness of the romantic was reinforced by the realization that individuals were now isolated in 'urban deserts', and that the communitarian aspects of social life had been eroded, a phenomenon later documented by sociologists, for example, by Tönnies (1887), who descried the deterioration of the folk Gemeinschaft (see also Durkheim, 1893/1997, chap. 2-3; Nancy, 2008; Carney, 2019). This sense of nostalgia, of sadness about loss, became a dominant 
feeling associated with romanticism. Some romantics strove, as a kind of quest, to restore some lost world, at least in imagination and artistic expression - in a poetization or aestheticization, of the present, while others sank into resignation, and a deep sense of alienation (Löwy \& Sayre, 2001, pp. 21-23).

\subsection{Romantic Notions of Alienation}

The advent of a rational, scientific world-view, the romanticists believed, came at a high price, a "painful and melancholic conviction" that essential values have been alienated, an alienation "often experienced as exile," so that the human soul had been rendered homeless; "the feeling of homelessness... and loneliness became the fundamental experience" of the Romantics at the beginnings of the nineteenth century (Hauser, 1999, p. 163). The past emerged in consciousness as nostalgia for an idealized period in which various forms of modern alienation - of normlessness, meaninglessness, and self-estrangement - did not yet exist, an imagined magical time when "the human values that had been since stifled by modernity were still operative," an orientation to the past that stretched into an imagined, "dreamed-of future beyond the contemporary world" (Löwy \& Sayre, 2001, p. 22).

The early romanticists linked the concept of alienation to a feeling of having been separated from someone, or something, with which one should be reunited. This belief, reinforced by the distressing, violent episodes of the modern world, impressed upon the romantic imagination a vague sense of malaise, which was given several names, including 'alienation' [Entfremdung], 'estrangement' [Entäusserung], 'separation' [Trennung], 'division' [Entzweiung], and disenchantment [Enttäuschung]; these terms all refer to something that should have a unity rather being opposed to itself. Insofar as individuals are responsible for their own destiny, alienation, the most general of the above terms, meant self-enslavement, a paradoxical situation pointed out by Rousseau (1762b), who began his Contract Social with the remark, "Man is born free; but everywhere he is in chains." As understood by the Romanticists, there were three basic levels of alienation: (i) A division between calculative-analytic reason and imagination-sensibility, which was seen, in part, as a result of occupational specialization and the detailed division of labor in civil society. (ii) Atomism was associated with the breakdown of communities, families, and guilds, and its replacement with the competitive marketplace, which compelled individuals to pursue their self-interest even at the expense of others, with entrepreneurs engaging in a kind of ruthless anomie (TenHouten, 2016). And (iii), there had emerged a separation of the self from nature. The Romanticists saw alienation as a key feature of human nature, with the root of alienation being "uprootedness, intellectual curiosity, man's heightened consciousness, and the unrest of freedom, where there is a separation between one's inner and outer worlds" (Pribic, 2008, p. 5).

Besides bemoaning the loss of spiritual meaning developing in the wake of the Enlightenment and the Scientific Revolution, many romanticists opposed religious dogma. In particular, they denounced the sexual asceticism long advanced by Christianity and propounded by Kant (1775-1780/1963, pp. 163-167; 1797/1996, p. 62), who described sexual union as a necessarily exploitative, objectifying, and undignified. While Christianity advocated transcending alienation by experiencing a higher plane of being, romanticism provided a more secular understanding of alienation, and advocated its transcendence through experiences beyond the limits of bourgeois morality. Indeed, the term 'alienation' became a widely-used catchword for romantic intellectuals' conceptualizations of nature, which referred less to the life of plants and animals than to humans doing 'what comes naturally'. The Jena romanticists demanded liberation from a bourgeois, Christian morality, which they blamed for having kept humanity from the erotic pleasures and had thereby alienated humanity from nature. While Christianity advocated transcending alienation by experiencing a higher plane of being, a far-off, divine world beyond sexuality, Jena romanticism provided a more secular understanding of alienation, advocating celebration of the passions, in a determined effort to transform conventional bourgeois life, with its rigid social conventions and its limitation of sexual behavior to procreation; for the romanticists, the world of sexuality was extended far beyond the institution of marriage, for it came to includes seduction, homosexuality, libertine sexuality, even incest, and revealed the means whereby humanity can rise above the estrangements of ordinary experience. Through the sexual enjoyment of women, Hoffman's Don Juan believed, the resulting longing enables an erotic communion with the supernatural which transcends man's alienation from higher existence.

The Jena romanticists enthusiasm for sexual passion opposed not only Hegel but also Goethe, who in his novels (e.g., Hermann und Dorthea) emphasized that whatever emotions of attraction tug at a married person, under no circumstances is the abandonment of wedlock morally acceptable; such an individual must be resigned to suffering and bow to the yoke of convention. The Jena circle rather advocated, and acted upon, their own self-styled, absolute freedom, significantly including free love. In F. Schlegel's unfinished novel, Lucinde, the autobiographical actor articulates this demand for complete individual freedom, and scandalously extolls the union of sexual and spiritual love as an allegory of Eros. In this novel the putatively superior romanticist seduces by means of a sophistical argument, convincing a girl to prove the freedom and depth of her love by giving herself sexually. In Lucinde, there was erotic, violent description of various modes of lovemaking, scandalous at the time but tame by today's standards. 
Besides its "preponderantly sexual connotation" (Feuer, 1969, p. 7), the romantic concept of 'alienation from nature' developed at least two additional meanings. First, Fichte (1794) suggested that, although modern humanity had become estranged or alienated from nature, it could be reconciled to nature through humankind's entitlement to overcome anything in nature that is alien to the human mind. Second, the early German romanticists, Schlegel (1799) and Novalis (1798-1799), conceptualized overcoming alienation from nature as the recognition that nature is greater than, and cannot be fully understood by, humans. We are, they pointed out, merely limited parts of nature's all-encompassing domain. (Stone, 2014).

Romanticism, as an alternative to science, offered a pseudo-scientific world view intended to overcome alienation from nature, from what they saw as the oppressive Enlightenment morality crystallized in Kantian ethics, and from the Christian-Enlightenment explanatory ideologies. Attempting to escape the dilemmas and disturbing implications of modern science, romanticists endeavored to replace the 'mechanical philosophy' (including the doctrine of predestination) with an organic view of the cosmos, For example, many philosophers that posited the existence of matter obedient to mathematical laws had concluded that there is no free will. The romanticists opposed this reasoning by imagining a universe that is essentially mental, arguing that the natural world is the ego's field of moral activity, the 'nonego'. Whereas Western philosophy had held that whatever is 'lower' or further from perfect must have been created by something 'higher' (Plato's 'Supreme Good', Christianity's 'God'), romanticists posited the reverse, that the 'higher' develops from the 'lower', so that an imperfect world develops and evolves. This evolutionary, romantic position conceptualized history as a teleological process, in which emerging human consciousness would become capable of fully comprehending the conditions of its own existence. In this romantic imagery, the world is no longer a 'great engine' or 'mechanism' but rather a great organism, a 'cosmic animal', wherein Nature is an unconscious Spirit striving for consciousness. Rivers thus do not fall mechanically into the sea; they rather organically strive to the sea. In the romanticists' endeavored to overcome 'the alienation of nature', their philosophical refutation of science and its quantitative, logical, and mathematical reasoning led them to the idea of a dynamically changing biological and ethical human nature, to an evolving universe in which everything is alive and organic (Eichner, 1982, pp. 16-17). The romantics were on a quest for spiritual ecstasy, unity with nature, self-fulfillment, and the restoration of human community.

The romanticists were the first to use the concept of alienation on a regular basis, which emerges from feelings of separation from someone, something, with which one should be united. They felt alienated by their own intellectuality and by life in cities, which they regarded as separating them from their fellow citizens, as inhibiting the attainment of their true nature. The romanticists thus saw their own self-alienation as accompanied by social and cultural alienation, and they came to the conclusion that society enslaves individuals, does not tolerate bold actions, and curtails the exercise of human freedom. Even worse, society stimulates egoism and encourages social striving. They came to see modern individuals as increasingly self-alienated through contradictions in their own character, being outwardly sympathetic and friendly to others, yet capable of acting as vicious and immoral monsters, capable of cruelty to animals and humans, able to enjoy and feel aroused by viewing and participating in sadistic torture, vivisection for 'scientific' purposes, and grisly executions (Steintrager, 2004).

Bereft of patronage, the romantic, creatively self-expressive artists of the nineteenth century faced a public that was often hostile, and they felt isolated and estranged from their societies (Kravitt, 1992). Romanticists advocated the free expression of artists' passions and emotions, especially awe, apprehension, terror, the sublime experience of untamed nature, and the exotic, unfamiliar, strange, unbound, and indefinable. For romanticists, "a purely rational existence negated life itself" (Koch, 2005, p.123), whereas strong passions and emotions enabled authentic, aesthetic experience. Romanticists especially sought to revive the emotions of pride and sensuality that Christianity had suppressed; they also encouraged naïve credulity, love of wonder, the reenchantment of a disenchanted world, the experiences of agony and bliss.

\subsection{Schiller's Romantic View of Work Alienation}

Friedrich Schiller (1794), drawing on Rousseau (1754, 1762b) envisioned an idealized past, in ancient Hellenistic civilization, where people had been truly human, living together in harmony and wholeness. Like many romanticists of his day, Schiller believed that the advent of modern society, with its detailed division of labor and specialization within the sciences, meant that humanity, which once had known wholeness and unity, had become fragmented, and alienated from both nature and the nature of human being. According to Schiller, modern society had undermined institutions that encourage the flourishing of the individual, and thus plunged them into an abyss of unsociable experience. Society now measured individuals by their work activities, so that workers were increasingly only cogs in a machine. The resulting fragmented, crippled, wounded existence was not limited to the workplace, for individuals' very personality and humanity were eclipsed by these oppressive circumstances. Schiller (1794/2004, pp. 29, 31-32, 38-40, 73-74) claimed that a disparity had developed between man's physical existence, "in time," and his abstract reason, or intellectual nature, "in idea." Every individual's task, Schiller asserted, was to overcome being at odds with one's self. Schiller saw an historical 
progression based on a dialectical antithesis between nature (material phenomena, multiplicity) and reason (form, unity, and the moral demands of consciousness). After the Hellenistic Golden Age, the antagonism of these forces had led to the virtual disintegrated the human personality, a fall of humanity to be reconciled in a renewed wholeness, in the perfected moral order that can come about through aesthetic education, which Schiller saw as the only possible way to reestablish human freedom and contentment.

Schiller (1794/2004) argued that the development of a modern, capitalist society necessitated the specialization of ranks and occupation in the economy, wherein the worker was reduced to "an ingenious piece of machinery, in which out of the botching together of a vast number of lifeless parts a collective mechanical life results," wherein "enjoyment was separated from labor;" and (iii), there emerged a more intricate machinery of governmental bureaucracy, the "clockwork of the state." These interrelated developments had severed the unity of human nature, so that "the essential bonds of human nature were torn apart, and a ruinous conflict set its harmonious powers at variance" (pp. 39-40). Schiller, (1794/2004, p. 39) wrote:

Eternally chained to only one single little fragment of the whole, Man himself grew to be only a fragment; with the monotonous noise of the wheel he drives everlastingly in his ears, he never develops the harmony of his being and instead of imprinting humanity upon his nature he becomes merely the imprint of his occupation, of his science.

Workers in the 'satanic mills' of the new industrial age were thus stultified, atrophied, anaesthetized victims of a vast industrial machine. Coser (1984, p. xii), writing of this misery and degradation, proclaimed: "The human beings now bound to the Ixion's wheel of the modern factory has become suffering victims instead of happy beneficiaries of the new division of labor." And, as Currie (1974, p. 34) put it, "Schiller's bureaucratic cog had become Marx's cotton-working cog, a different employee who, nevertheless, suffers the same alienation" (p. 34).(note 4)

Overcoming this alienation, Schiller argued, requires a balancing of "sensuous nature" and "reason." Marx, focused mostly on sensuous nature, described effects of fragmented, repetitive work. This idea he derived from Schiller (1794/2004), who had written that for workers, and more generally modern individuals, "mental faculties show them in idea, and we see not merely individual persons but whole classes of human beings developing only a part of their capacities, while the rest of them, like a stunted plant, shew only a feeble vestige of their nature" (p. 38). Schiller added that, "by combining our activities to a single sphere we have handed ourselves over to a master, who is not infrequently inclined to end up by suppressing the rest of our capacities" (p. 39).

\section{Hegel, the Anti-Romantic}

Under the influence of the proto-romantic Rousseau and participants of the romantic movement, the concept of alienation entered into general use in the eighteenth and early nineteenth centuries. Hegel's 1807 Phänomenologie des Geistes (hereafter, Phenomenology) focused on alienation as "a key concept" (Hyppolyte, 1997) and a serious issue for moral and social philosophy. Indeed, Hegel's entire philosophy arguably "assigns a central role to the problem of the alienation of the self and the overcoming of it" (Gadamer, 1976, p. 106).

Several scholars_-including Mead (1936/1972, pp. 127-151), Abram (1973), Rothbard (1995: chap. 11), Beiser (2003), and Deakin (2015), have described Hegel as a romantic, for various reasons. First, Hegel's Phenomenology was roughly parallel to, but was not derived from, the romanticists' notion of organicism, the belief in an evolving World Spirit (Geist) moving from a lower to a higher state of organization. Both romanticists and Hegel took part in the timeless metaphysical story in which there is a painful education of the conscious subject as it strives, not realizing what it was actually seeking until it is attained, which is to win it way back to a unity with itself, a unity which it had, through a primal act of consciousness, alienated itself. While romanticists and Hegel both indulged themselves in this myth of the 'great circle', this story is ancient and Hegel's sourcing for his own narrative was independent of romanticism (Abram, 1973).

Second, Hegel shared romanticism's fundamental goal, Bildung, the education of humanity, the development, or building, of human powers as a whole, a project whose goals were gaining understanding of the nature and capabilities of the human mind. For the romanticists, Bildung referred to the reaffirmation of the value of unity, of feeling at home in one's self, society, and natural environment, and the formation, or building, of self-realization. We will, however, see that romantics and Hegel held antithetical views about how such development of self-consciousness could possibly emerge.

Third, it has been argued that the romanticist Novalis's work bears parallel to, and might have influenced, Hegel. There is, however, scant indication of this, and Hegel seldom mentioned Novalis. While both referred to a unity of poetry and philosophy, and of the finite and the infinite, these were common topics for thinkers of this time. Moreover, while Novalis produced only fragmentary and employed multiple genres, Hegel's scholarship was highly systematic. Hegel derisively described the Jena romanticism as "morbid, overly emotional, and pathologically introspective" (Ezekiel, 2019).

And fourth, whereas romanticists held a negative view of alienation, Hegel rather presented a positive view of alienation, 
as painful but necessary for the advancement of concepts, of human understanding, the acquisition of human power to reason and master the world, and the development of the self. This is the crucial difference between Hegel and Romanticism, which requires elaboration.

\subsection{Hegel's Critique of Sentimentalism}

Sentimentalists, beyond their concerns for moral judgments, advocated following one's own heart, and remaining in harmony with one's own nature, which they saw as a way to advance human welfare. Hegel considered sentimentalism a heart-throb leading to conceit and disdain for others, as it provokes the same violence against humanity that moral sentimentalists had initially condemned. The sentimentalist, Hegel maintained, "is clearly not ready to 'entrust' [anvertraub] his inner life to the alienating forces of mean reality" and "his heart now pounds in a fury for self-preservation" (Hegel, 1807b/2013, § 374). Hegel instead advocated bringing one's emotions into the social world, where one's inner feelings are no longer fully one's own, and one's emotional life becomes subjected to "the alienating objectivity and heartlessness of the public sphere" (Hegel 1807b/2013, § 372). For Hegel, self-realization required a positive kind of self-alienation (Pahl, 2012, p. 26), where the self in-itself transcends its pathological state of mind and "participates in the spirit's progression of self-knowing" (Reid, 2007/2019, p. 88). While the Sentimentalists had insisted that one's heart is one's most precious possession, Hegel rather interpreted the sentimentalists' resistance to the alienation of feelings from the self to mean that they neither feel much nor actually think.(note 5) Hegel advocated "acknowledging the alien within the self as a constitutive part of emotional and conceptual transport" (Pahl, 2012, p. 26). Thus, for Hegel, Spirit welcomes alienation [Entfremdung], disruption, and exposure to the world. With such exposure, the individual no longer retains and possesses its self as a stable essence, but rather externalizes the inner self and exposes it to possible change (Hegel 1807b/2012, § 312). Hegel thus celebrated alienation as necessary for self-realization: "what used to be called 'inner' has already become other; it is alienated in a good sense" (Pahl, 2012, p. 31). The painful nature of this alienation lies in contraction between subjective emptiness and essential objectivity, expressing the subjective desire to reconcile with increasingly substantial objective contents (Reid, 2007/2019, p. 89).

\subsection{Hegel's Critique of Romanticism}

The cénacle, a small group of romantics, gathered in Jena in 1798, around the Athenäum review, was led by the central theorist of romantic irony, Friedrich Schlegel, in collaboration with Schleiermacher, Novalis, and his brother, Karl Schlegel. F. Schlegel saw alienation in the constraints imposed by conventional bourgeois, Christian morality on the free expression of sexuality (West, 2005, pp. 125-178). (note 7) Hegel, who arrived in Jena in 1801, was appalled by Schlegel, portraying him, albeit indirectly, as sophistical and an evil seducer bent on "abandonment to the sensual," who immorally claimed that "a state of nature...possesses rights." Hegel, following the ascetic-idealist tradition, looked down on sexuality, referring to it only indirectly, as a factor of life which apart from the marriage relation, cause a sense of shame, and within marriage involves a necessary bargain for mutual use (see Žižek, 2012).

Whereas romantics and Hegel both utilized the notion of Spirit [Geist], their understandings of this concept differed radically. For romanticists, spiritual experience is confined to individual minds; but for Hegel, the dialectical advancement of Spirit is of world-historical developments, including both philosophy and science, social institutions encompassing the legal system, organized religion, and the state. While romanticists and Hegel both sought consciousness of life-giving power, for romanticists a Dionysian power is found in ecstasy, exaltation, and enlightenment of the individual mind; but for Hegel, an Apollonian philosophical exultation culminates in the power of escaping the limitations of empirical existence through a gnostic dialectic, an active and intentional grasping of a world-conquering force, a subjecting of the world to the dictates of human reason, the subject's proud conquering of objectivity. Hegel's Spirit of self-consciousness, for the individual, was a freedom to exert one's will and feel itself as power. Romanticists' and Hegel's notions of power led to different experiences. For the romanticists, the experience of power was a very private matter, which typically was not appreciated by the larger community. Many romantics were denied even this experience, and lacked social support, finding themselves languishing in depressive moods that could reach despondency or even despair, giving up, and engaging in self-destructive behavior, even creating a mystique surrounding suicide. Novalis, in particular articulated a yearning by, and a sickness of, the delicate soul, succumbing, at age 29, to tuberculosis. (note 8 )

Hegel was strenuously opposed to early German (Jena) Romanticism and, was a harsh critic of romanticism's celebration of inner intuitionism (Reid, 2007). Hegel saw that these romanticists' ironic subjectivity posits a world that excludes the possibility of attaining objective truth through thinking, and can only reject or escape the world through scandalous pleasure-seeking (Schlegel), sentimental religiosity (Schleiermacher), or to self-destructive action leading to the despair and death of the 'beautiful soul' (Novalis, with his melancholic Hymns to the Night). Hegel's critique of romanticism, initiated in Phenomenology, was expanded in his later argument that the world can be understood, made rational, to the extent that it is penetrated by objective thought and a scientific logos, an objectivity not reached by the romantic self, an aloof 'I', that floats above objective as reality, as a subjective vanity, a sophistry claiming to possessing 'worldly wisdom' 
[Weltweisheit] that makes of itself the master of reality, which Hegel (1820/2005; see also Reid, 2007/2019, pp. 11-22) explicitly attributed to Schlegel.

\subsection{Hegel's Self in the Social World}

An apocalyptic view of human history advanced both by romanticists and by Gnostics, was also embraced by Hegel. Humans, Hegel argued, are the vehicles of a self-creating, absolute Geist. In order to gain a de-alienating self-consciousness and attain self-realization, this Geist must advance through 'dialectical' steps in order to gain the knowledge necessary to overcome alienation from nature and from one's fellow humans. In Phenomenology, Hegel elevated alienation to a serious issue for moral and social philosophy. Hegel distinguished between the alienation of property [Entäusserung] and the alienation of self, or self-estrangement [Selbstentfremdung]. By self-estrangement, Hegel meant the dissociation of the 'self' into an actor, an 'I', a subject striving to control its own destiny, and a 'me', an object, whose identity is, in part, controlled by others, or is socially constructed by the understanding that others have of this 'me'.

Romanticist thinkers had considered aesthetic experiences and feelings to be self-centered, contained within the mind of the individual, and private, immediate, and unreflective. Rousseau argued that emotions would be destroyed if they were given conceptual basis, and members of the Sturm und Drang refrained from giving name to their emotions, believing there is nothing in a name but empty vapouring and the potential for undermining the experience of being swept along by ecstatic enthusiasm. Hegel, in opposition to this notion of keeping emotions private and interior to the self, rather proposed that for one's consciousness to become self-willed and free, it is necessary to overcome a subject-object duality, an accomplishment enabling productive engagement in emotion-laden social relations. Hegel saw feeling and emotion not as encapsulated in the mind, but rather as disruptive, confused, ambiguous, and sometimes inauthentic and manipulative in their expression and associated behavioral responses. Hegel's 'dialectical' development of self-consciousness requires that emotions are necessary to "transport the self out of itself, a distancing of the self from itself, necessary for the attainment of a changed self, a process that and takes place within 'a texture of sympathy'" (Pahl, 2012, p. 5). Self-developed thus requires involvement with other selves, which have their own interests and agendas. Such transport requires the capacity for self-negation [Aufhebung], which generates a changed self out of the inner contradictions of one's former self. This self-negating process is affect-laden, and manifests in feelings of brokenness, trembling, tears, and laughter (Pahl, 2012, pp. 84-99, 152-212, 222-223). In such transports, or transitions, the components of the former self do not disappear. Rather, the changed self must encompass, and relate to, its former nature. In Hegel's account, reason, if it is not to be held aloof, 'raised above perception' [erhoben über die Wahrnehmung], must have emotional qualities, as emotionality "is analytic and self-reflective in that it registers and thus reinforces self-incongruity" (Pahl, 2012, pp. 36-37). Thus, the self cannot, as romanticists believed, develop itself by engaging in as calm and detached manner, for the self is essentially social, and engagement with the social cannot be attained with pure reason, but requires an interaction of cognition, social perception, and emotion.

In Hegel's Phenomenology the 'unhappy consciousness' [unglückliches Bewusstsein] is a self-estrangement [Selbstentfremdung], or a despairing state of mind in which the individual cannot reconcile opposites internal to the self. The unhappy consciousness, while a step beyond skepticism, is nonetheless painful because it is nothing but the subjective desire to unite with objectivity. The path of self-development and the overcoming this unhappy level of consciousness is not, as Fink (1977, p. 42) and Solomon (1983, p. 227) would have it, a rather painless progression, or development, from darkness to light, for Hegel rather presents self-development as necessarily a self-alienating "path of despair" [Weg der Verzweiflung] (Pahl, 2012, p. 181), wherein the subject must experience "the loss of itself" (Hegel, $1807 \mathrm{~b} / 2012, \S 78$ ). In this discontinuous process, one realizes that the self is not a given, for self-development requires that a subject must accept being consumed, shattered, and painfully broken in the process of the "long and ongoing path of formation-where we reach the self-alienated spirit of cultural maturation [Bilding]...[and where] the protagonist...registers the despair of this journey" (Pahl, 2012, p. 82; see also Hegel, 1807b/2012, § 77). In 'dialectical' moments of self-transition, the self experiences disorganization of rational thought amidst a profound self-doubt or "self-consummating skepticism" [sich vollbringende Skeptizismus] (Hegel, 1807b/2012, § 78). To advance, the self must choose an introjected despair over an extrojected doubt. Despair is interior to self-development, and manifests itself in events of self-transition, which never reach a state of completion, so that self is discontinuous and unstable rather than a self-contained, stable unity. The effective self, in confrontation with the social world, must be flexible and attain a level of or plasticity (Malabou, 2005) by productively alienating itself from itself, welcoming changes that leave aspects of one's former self behind. It is only by participation in the social world that the self is able to confront itself as a self in despair. But this confrontation is no exercise in rationality, for such tropes of transit necessarily involve the emotions; emotions, far from being self-contained as inner content, are rather intrinsically ambiguous insofar as they are never fully inside or outside, being both of the mind and embedded in social relations. As Terada (2004, p. 22) observes, emotions do not simply aggrandize the self by appropriating the other, for we feel to the extent that our own experience seem like someone 
else's, which estranges the self from itself, making of selves objects of themselves, so that, as Hegel 1807b/2012, § 790) put it, "the being of the I is a thing."

The self-estranged individual experiences a psychic emptiness, but "cannot live in a condition of emptiness for very long; if he is not growing toward something, he does not merely stagnate; the pent-up potentialities turn into morbidity and despair" (May, 1953, p. 24; see also TenHouten, 2017a, pp. 101-102). It is only when the self is open to the world, Hegel correctly asserted, that the subject can experience others and otherness, and thereby participate in the life of the world, in history, politics, economics, culture, and community. At the end of Phenomenology, Hegel asserted that the romanticists' 'beautiful soul' can come out of its fixation in its moment of the for-itself, its pathological condition [Gemüt] of being but a nothingness, and experience a 'positive alienation', thus participating in the progression of Spirit's self-knowledge.

Because self-identification relies on reason, the despairing individual becomes acutely aware of, and reliant upon, his reason while at the same time repressing the emotional energy that would enable facing the world and risking change. As Pahl (2012, p. 192, referring to Nancy, 2002, p. 35) puts it, "By cultivating the power of distance and analysis, man protects himself against destabilizing effects of despair's 'being-of-itself-outside-itself-in-the-other'." The individual in deep despair detaches from the flux of life, building a defensive cognitive edifice, and thereby attaining an "isolated freedom" in which one develops a "hypnotic fixation - facing death or look[ing] the negative in the face" (Hegel, $1807 \mathrm{~b} / 2012, \S 32$ ), as one descends to a "pure I," which is but a magical "abstraction with no actuality" Surrendering to despair, the epigenetic operation of the "pure I...takes the shape not so much of a self-birth as of a suicide" (Pahl, 2012, p. 192). The self, clinging to a detached rationality and refusing engagement with the world, becomes a dead self, and despair becomes a defining emotion, because to "hold fast to what is dead requires...the greatest force." This individual, fearing the world's ability to destabilize its self, develops a hard heart. As Pahl (2012) continues, Hegel's notion of the hardened heart led him to the conclusion that, "The very impossibility of experiencing despair is one of the main characteristics of despair... The inability to despair drives one to despair" (pp. 199-200). Despair is apt to be repressed, encapsulated, and masked by logical-sounding generalizations about the human condition, the existence or non-existence of God, or the consequences of suicide (Farber, 1999, p. 200). In a state of despair, an individual's forced logic can become hyperactive in a desperate effort to keep fears and doubts from the conscious mind. This level of self-estrangement means pursuing a tortured logic, in which the idea of being the author of one's own death exercises a seductive fascination (TenHouten, 2017a, pp. 99-101).(note 6)

\subsection{Alienation, Self, and Social Domination}

While the romanticists had seen alienation as a thoroughly negative phenomenon, for Hegel self-estrangement was painful, even torturous, but was nonetheless necessary for the development of the mind, and therefore was a positive kind of alienation. Hegel called this distancing of the self from itself the "unhappy consciousness [das unglücklicht Bewusstein], "the Alienated Soul which is the consciousness of self as a divided nature, a doubled and merely contradictory being" (Hegel, 1807a/1967, p. 251). Hegel's idea of alienation can be traced both to Gnosticism (Voegelin, 1952, 1968) and to apocalyptic religious visions from Paul to Luther (Barnes, 1988; Rotstein, 2018). This apocalyptic view of human history-advanced both in Christianity, especially by Paul and Luther, and in Gnosticism, was embraced by Hegel. Humans, Hegel argued, are the vehicles of a self-creating, absolute Geist. In order to gain a de-alienated self-consciousness and attain self-realization, this Geist must advance through 'dialectical' steps, to gain the knowledge necessary to overcome alienation. Closely following Luther's four-stage dialectic, Hegel argued for a sociohistorical process, a system of inversions [Umkehrung] consisting of a series of dialectical moments, as consciousness passes through successive stages of unity, separated opposites or 'self-alienated spirit', and reunion, not with some unchanging essence but rather with a changed mentality.

Hegel (1807) saw the subjective experience of alienation embedded in socially-oppressive circumstances of social domination, beginning with the relation between the lord and the bondsman [Herrschaft und Knechtschaft]. In this antithesis of lordship and bondage the bondsman (slave, serf, servant) at first internalizes the meaning systems, values, and desires of his lord or master. This subordinated self exists only as a being-for-another.

In the second stage, the bondsman remains confined to his inferior position but recognizes his freedom and independence in productive labor,(note 9) realizing that the lord is dependent upon this labor. Through work, the bondsman becomes an object to himself, and obtains freedom of self-consciousness, the ability to think for himself and in his own interest. Hegel called this stage of abstract freedom stoicism, which takes the form of doubting the reasons for one's own servitude, recognizing they are arbitrary, capricious, or accidental, and develops the idea of real freedom, the ability to act for one's own reasons and in one's own interest. But this abstract freedom of reflective thought is not yet actual freedom, for it remains devoid of social content.

In the third stage, stoicism is elevated to skepticism, the actual experience of freedom, in which self-conscious negation "procures for itself the certainty of its own freedom" (Hegel, 1807a/1967, p. 248). The freed skeptic sees contingency in 
all points of view, including his own, and therefore commits a performative error: the skeptic concludes that no claim can be validated, yet this claim contradicts or invalidates itself. This skeptical self-consciousness thus comes to know itself as a consciousness containing a massive contradiction within itself. This realization turns his bondage inside out, thereby reaching the stage of the unhappy consciousness, a stage of development that is debilitating, highly alienated, unstable, even despairing, wherein the 'I' of the self alternates between euphoric over-confidence about the powers of human reason and despair over the result that reason alone leads only to contingency and confusion.

In the fourth stage, there emerges a unity of subject and object, as alienation of the self from the world is overcome, and individuals become free and equal social beings, as the oppressive reality of social domination, of human bondage, is overcome, and freedom becomes an objective reality.

Thus, Hegel followed Luther in the structure of his dialectical development from oppression to liberation, but whereas Luther saw the path to salvation in an emptying of the self, Hegel resolved the problem in a opposite way, as he saw a progression from the human being as creature to creator of his own artifacts, thus linking the spiritual and the material planes of existence, resulting in a 'finite spirit' of the everyday world wherein consciousness and material existence are interdependent in 'life'. Hegel believed that alienation could be overcome by acts that connect the subject of being with the objects of the world. In his Herrschaft-Knechtschaft dialectic, Hegel had grasped that human beings, as the result of their own labor produce a consciousness aware of its own independence, a being-for-self, while also engaging in a being-for-others. Thus, alienation is overcome.

\section{Discussion and Conclusions}

The opposition of Hegel to romanticism was crystallized in their contrasting notions of alienation, both in relation to feeling and emotion, and in the nature of the self. The sentimentalists, and later the romanticists, saw the subjective experiences of imagination and emotion as fully interior to the self, yet finding self-expression in cultural productions. Rousseau proposed that feeling offers individuals protection from such a crisis of reason by means of "listening to the Voice of Nature in the most hidden part... of [their] intimacy" (Olaso, 1988, p. 56). Thus, feeling was seen as protective insofar as it remains interior to the self. In his notion of an evolving Spirit, Hegel was much in accord with the romantic view of Spirit evolving from a lower to a higher state. Hegel's notion of a dialectically evolving world Spirit, manifesting itself in space as nature, in time as history, and in mind as the embodiment of reason, was concept also explore in romanticism. Yet, despite this common proto-evolutionary bent, Hegel was an opponent of ironic romanticism. The sentimentalists, and later the romanticists, had valued emotion and imagination as interior to the self. Hegel flatly rejected this position, arguing that in order not to consume itself, and to reach its full potential, the self needs to separate from its innermost subjectivity, as it must engage in painful encounters with the objective world. The self so engaged in social relationships can only partially return to itself, and cannot full recover its former state. It is only through this social-psychological process of encountering the objective world of other people (largely through language use), which requires alienating the self from itself, that the self can develop itself and realize its full potentiality.

Feelings and emotions, fully subjective and interior to the sentimentalists and romanticists, were for Hegel rather deeply embedded in social relations. While the romanticists were reluctant to use words directly pertaining to their own feelings, and sought to thereby preserve the integrity of their inner experience, Hegel rather brought to the fore the self-disrupting, sociorelational qualities of emotional experience. Hegel realized that feeling and emotions cannot be expressed as an organic unfolding of one's inner character. In the process of communicating emotions, feelings, and sentiments, one's self is sure to be subjected to disruption, opposition, and the reality of other social actors whose own emotional expressions are adaptive reactions intended to satisfy their own needs, intentions, and goals.

Irony has been thematic in romanticism, and the final irony of romanticism as a philosophy is that while it was intended to transcend fragmented existence though the creation of a sense of unity, it has been cynically used to induce individuals to immerse themselves in largely inauthentic experiences, a simulacrum of unity and community (Baudrillard, 1981; C. Campbell, 1997; Ritzer, 1999) that lead to various levels of self-fragmentation and despair.

The romanticists had seen passion in a positive light, and Hegel did also, but in a different way. For Hegel, passion can have an ethical value, as he defined 'pathos' as passion for a cause. Pathos can motivate an individual to put into action what he sees as good and right. Passion which propels social action escapes the sentimentalists' and romanticists' view of passion as merely interior to the heart: Interiorized passions are prone to insincerity, for they can exist as private ends posing as universal purposes. For Hegel, passions elevated to pathos have the potential to reconcile emotion and reason, for passions motivate ethical social action only by being articulated with accepted reasons for such action. The resulting unity of pathos and reason enables heroic action based on a firm and steadfast commitment, together with a sense of ethical calling. Thus, passions linked to action can enable the individual to act positively and authentically in the social world, and in the process overcome any alienation of emotion and reason. At the same time, passions of agency such as ambition, love, and a thirst for glory, however well intentioned, can, in a tragic world, undergo an ironic reversal and bring 
about not bliss and success but despair and disaster.

Hegel and the romantics had radically different conceptualizations of the self. The romanticists imagined the self as an inner subjectivity that should be protected from exposure to the social world. While they focused on conscious sensitivity as a component of the self, they underestimated the importance of acting with intentionality in the everyday world for the development of the self (McGinn, 1989; Searle, 1991). Hegel rather saw the self as developing in engagement in the objective social world, progressing as it encounters, and resolves, inner contradictions. Hegel was right that the self is constructed, and develops, through often painful confrontations with social reality, but he was wrong in seeing the self as overcoming inner contradictions. Thus, there is also irony in Hegel, who saw the resolution of contradiction as productive of a coherent, reasoning self, a conceptualization which is itself contradicted by neuroscientific evidence that the healthy self prospers and develops with the attainment and elaboration of polysemantic context, the simultaneous processing of many kinds of information, and by seeing connections between disparate perceptions and images that produce a sense of wholeness. When this contradiction-tolerant totality breaks down, to be replaced by reliance on monosematic use of language, sequential information processing, analytic reasoning, simplified and reduced to unambiguous context, what follows is not the attainment of Spirit but the collapse of the self (Weinberg, 2000), a destructive self-estrangement that leads only to despair (TenHouten, 2017a, chap. 7).

This gestalt-synthetic mode of cognition is the dominant mode of thought of the right cerebral hemisphere of the human brain (of well-lateralized right handed adults), and the self, which requires a polysemantic view of reality, is also right-lateralized (Weinberg 2000; see also Alcaro Carta, \& Panksepp, 2017). If the self collapses, the individual can only maintain a monsemantic, logical-analytic, left-hemisphere dominant view of reality and, according to interhemispheric transfer-deficit theory, can only speak in a way that is symbolically impoverished (Hoppe, 1989) and is largely devoid of affect (alexithymic) (Hoppe \& Bogen, 1977; TenHouten et al., 1986, 2017a, pp. 99-101). This shift to a reliance on logic and on monosemantic context creates tendencies toward dissociation, alienated and negative perception of the body, reduced sensitivity to pain, disintegration of self-representation, cognitive impairment, anhedonia, distortion and overgeneralization of memories, difficulties of affect representation, and a reduced openness to new experience (for a review of this research, see Weinberg, 2000).

Thus, romanticism developed a global view of the self, but were wrong to value its interiority and in trying to protect it from the corrupted and corrupting social world. Hegel was right that the self is both subjective and objective, both inner and outer, but not in believing that the self can progress by resolving inner contradictions through some kind of 'dialectical' process. Hegel notion of dialectics was derived from an apocalyptic religious vision, and has established no standing whatever as a serious scientific concept. The self progresses and develops not through resolving inner contradictions but rather through incorporating and elaborating contradictions, ambiguities, polysemantic meanings, and a gestalt-synthetic mode of thought, all of which are necessary for attaining and maintaining an overall grasp of one's ever-changing place in the world. The self cannot rely on self-protective inwardness, as romanticists believed, because, as Hegel rightly insisted, the result is but an experience of emptiness. Hegel was correct in his contention that the self must engage in the often-painful objective realities of social life, but he was mistaken in his conceptualization of the self progressing and developing itself through successive resolution of contradictions, because a progression of the mind toward a world-view reliant on, and reduced to, all that is consistent with logic and reason, as shown by contemporary social neuroscience leads not to wisdom or enlightenment but rather to a vulnerable self estranged from itself, at risk for all kinds of pathologies of the mind and brain, possibly arriving at a state of despair, and ironically gaining a hollow victory, attaining the splendid isolation of the mind advocated by the romanticists.

\section{References}

Abram, M. H. (1973). Natural supernaturalism: Tradition and revolution in romantic literature. New York: W. W. W. W. Norton \& Company.

Alberoni, F. (1983). Falling in love (L. Venuti, Trans.). New York: Random House.

Alcaro, A., Carta, S., \& Panksepp, J. (2917). The affective core of the self: A neuro-archetypical perspective on the Foundations of human (and animal) subjectivity. Frontiers in Psychology, 8(1 September), 1424. https://doi.org/10.3389/fpsyg.2017.01424

Baier, A. C. (1991). A progress of sentiments: Reflections on Hume's Treatise. Cambridge, MA: Harvard University Press.

Barnes R. (1988). Prophesy and gnosis: Apocalypticism in the wake of the Lutheran Reformation. Stanford, CA: Stanford University Press.

Barrett, M. (2017). The romance of tuberculosis. The Week (May 13). https://theweek.com/articles/692701/romance-tuberculosis 
Baudrillard, J. (1981/1994). Simulicra and simulation (S. F. Glaser, Trans.). Ann Arbor. MI: The University of Michigan Press.

Beiser, F. C. (2003). The romantic imperative: The concept of early German romanticism. Cambridge, MA: Harvard University Press.

Bennett, A. (2015). Shame and sensibility: Jane Austen's humiliated heroines. Studies in Romanticism, 54(3), 377-400. https://www.jstor.org/stable/43973910

Borges, M. (2019). Emotion, reason and action in Kant. New York: Bloombury Academic Press.

Bowra, C. M. (1949/1961). The romantic imagination. New York: Oxford University Press. https://doi.org/10.4159/harvard.9780674733800

Campbell, C. (1987). The romantic ethic and the spirit of modern consumerism. Cambridge, MA: Blackwell Publishers.

Campbell, S. H. (2012). Rousseau and the paradox of alienation. Lanham, MD: Lexington Books.

Carney, T. P. (2019). Alienated America: Why some places thrive while others collapse. New York: HarperCollins.

Charleton, W. (1674). Natural history of the passions. London: Printed by T. N. for James Magnes.

Coser, L. (1864). Introduction. In É Durkheim, The division of labor in society (W.D. Halls, Trans.) (pp. ix-xxiv). New York: The Free Press.

Crocker, L. G. (1963). Nature and culture: Ethical thought in the French Enlightenment. Baltimore: Johns Hopkins University Press.

Currie, R. (1974) Genius: An ideology in literature. New York: Schocken Books.

Darwall, S. (1988). Empathy, sympathy, care. Philosophical Studies, 89(2-3), 261-282. https://doi.org/10.1023/A:1004289113917

Deakin, W. (2015). Hegel and the English romantic tradition. New York: Palgrave Macmillan. https://doi.org/10.1057/9781137482181

Descartes, R. (1649/1989). The passions of the soul (S. H. Voss, Trans.). Indianapolis, IN: Hackett Publishing Company.

Durkheim, É. (1893/1997). The division of labor in society (W. D. Halls, Trans.). New York: The Free Press.

Eichner, H. (1982). The rise of modern science and the genesis of romanticism. Publications of the Modern Language Association of America, 97(1), 8-30. https://www.jstor.org/stable/462237

Etzioni, A. (1968). The active society: A theory of societal and political processes. New York: Free Press.

Ezekiel, A. (2019). Novalis (George Philipp Friedrich von Hardenberg) (1772-1801). Internet Encyclopedia of Philosophy. Retrieved March 3, 2019, from https:www.iep.utm.edu/novalis

Farber, L. H. (1999). Despair and the life of suicide. Salmagundi, 123(Summer), 191-209.

Feuer, L. S. (1969). Marx and the intellectuals: A set of post-ideological essays. Garden City: Doubleday.

Feuerbach, L. (1841/1947). The essence of Christianity (G. Eliot, Trans.). New York: Harper.

Fichte, J. G. (1794/1847). The vocation of the scholar (W. Smith, Trans.). London: J. Chapman.

Fink, E. (1977). Hegel: Phänomenologische intreptetationen der phänomenologie des geistes. Frankfurt am Main, Germany: Vittorio.

Frazer, M. L. (2010). The enlightenment of sympathy: Justice and the moral sentiments in the eighteenth century and today. New York: Oxford University Press. https://doi.org/10.1093/acprof:oso/9780195390667.001.0001

Gadamer, H. G. (1976). Hegel's dialectic: Five hermeneutical studies (C. P. Smith, Trans.). New Haven, CT: Yale University Press.

Godwin, W. (1831). Thoughts on man, his nature, productions and discoveries. London: Effingham Wilson Royal Exchanges.

Goodall, J. (2016). Electrical romanticism. In C. Knellwolf \& J. Goodall (Eds.), Frankenstein's science: Experimentation and discovery in romantic culture (pp. 117-132). New York: Routledge.

Gordon, S. L. (1981). The sociology of sentiments and emotions. In M. Rosenberg \& R. H. Turner (Eds.), Social psychology: Sociological perspectives (pp 562-592). New York: Basic Books. https://doi.org/10.4324/9781315129723-18

Haidt, J. (2001). The emotional dog and its rational tail: A social intuitionist approach to moral judgments. 
Psychological Review, 108(4), 814-834. https://doi.org/10.1037/0033-295X.108.4.814

Haidt, J. (2012). The righteous mind. New York: Pantheon.

Hauser, A. (1999). The social history of art (4 vols) (S. Goldman, Trans.). London: Routledge \& Kegan Paul.

Hegel, G. W. F. (1807a/1967). The phenomenology of mind (J. B. Baillie, Trans.). New York: Harper \& Row.

Hegel, G. W. F. (1807b/2012). The Phenomenology of spirit (T. Pinkard, Trans.). Retrieve December 2, 2018, from http://web.mac.com/titpaul/Site/Phenomenology_of_spirit_pge.html

Hegel, G. W. F. (1820/2005). Philosophy of right. (S. W. Dyde, Trans.). Mineola, NY: Dover Publications.

Hobbes, T. (1640/2009). The elements of law natural and politic. Gloucester, UK: Dodd Press.

Honour, H. (1979). Romanticism. New York: Harper \& Row.

Hoppe, K. D. (1989). Psychoanalysis, hemispheric specialization, and creativity. Journal of the America Academy of Psychoanalysis, 17(2), 253-269. https://doi.org/10.1521/jaap.1.1989.17.2.253

Hoppe, K. D., \& Bogen, J. E. (1977). Alexithymia in twelve commissurotomized patients. Psychotherapy and Psychosomatics, 28(1-4), 148-155. https://doi.org/10.1159/000287057

Hume, D. (1739/1978). A treatise of human nature (2nd ed.) (L. A. Selby-Bigge, Ed.). London: Clarendon Press. https://doi.org/10.1093/oseo/instance.00046221

Hume, D. (1748/1986). Enquiries concerning the human understanding and concerning the principles of morals (L. A. Selby-Bigge, Ed.). Oxford: Clarendon Press. https://doi.org/10.1093/oseo/instance.00032980

Hutcheson, F. (1725/2004). An inquiry into the origin of our ideas of beauty and virtue in two treatises (W. Leidhold, Ed.). Indianapolis, IN: Liberty Fund.

Hutcheson, F. (1728/2003). An essay on the nature and conduct of the passions and affections with illustrations on the moral sense (A. Garrett, Ed.). Indianapolis, IN: Liberty Fund.

Hyppolyte, J. (1997). Logic and existence (L. Lawler \& A. Sen, Trans.). Albany, NY: State University of New York Press.

James, S. (1997). Passion and action: The emotions in seventeenth-century philosophy. New York: Oxford University Press.

Jeffries, L. B. (2007). Above the sea of fog: The new romantic era of video games. Retrieved April 25, 2019, from https://www.popmatters.com/above-the-sea-of-fog-the-new-romantic-era-of-video-games-2496246654.html

Kahneman, D. (2011). Thinking, fast and slow. New York: Farrar, Straus and Giroux.

Kant, I. (1775-1780/1963). Lectures on ethics (L. Infield, Trans.). New York: Harper \& Row.

Kant, I. (1785/1964). Groundwork of the metaphysics of morals (H. J. Patton, Trans.). New York: Harper \& Row.

Kant, I. (1797/1996). The metaphysics of morals (M. J. Gregor, Trans.). New York: Cambridge University Press. https://doi.org/10.1017/CBO9780511809644

Kauppinen, A. (2018). Moral sentiments. Stanford Encyclopedia of Philosophy (Winter 2018 edition) (E. N. Zalta, Ed.). https://plato.stanford.edu/entries/moral-sentimentalism/

Koch, A. M. (2005). Romance and reason: Ontological and social sources of alienation in the writings of Max Weber. London: Rowman \& Littlefield.

Kravitt, E. F. (1992). Romanticism today. The Musical Quarterly, 76(1), 93-109. https://doi.org/10.1093/mq/76.1.93

Kuhn, B. (2009). Autobiography and natural science in the age of romanticism: Rousseau, Goethe, Thoreau. New York: Routledge.

Locke, J. (1690/1995). An essay concerning human understanding. Amherst, NY: Prometheus. https://doi.org/10.1093/oseo/instance.00018020

Lovejoy, A. O. (1936/1965). The great chain of being: A study of the history of an idea. New York: Harper \& Row.

Löwy, M., \& Sayre, R. (2001). Romanticism against the tide of modernity (C. Porter, Trans.). Durham. NC: Duke University Press. https://doi.org/10.1215/9780822381297

Malabou, C. (2005). The future of Hegel: Plasticity, temporality and dialectic (L. During, Trans.). London: Routledge.

Malebranche, N. (1674-1675/1997). The search after truth, (T. M. Lennon \& P. J. Olscamp, Trans. and Eds.). New York: Cambridge University Press. 
May, R. (1953). Man's search for himself. New York: Dell Publishing.

McGann, J. J. (1982). Romanticism and its ideologies. Studies in Romanticism, 21(4), 573-599. https://doi.org/10.2307/25600395

McGinn, C. (1989). Can we solve the mind-body problem? Mind, 98(291), 349-366. https://doi.org/10.1093/mind/XCVIII.391.349

Mead, G. H. (1936/1972). Movements of thought in the nineteenth century (M. H. Moore, Ed.). Chicago: University of Chicago Press.

Mullan, J. (1988). Sentiment and sociability: The language of feeling in the eighteenth century. Oxford: Clarendon Press.

Murray, C. J. (2003, 2004). Encyclopedia of the romantic era (2 vols.). New York: Fitzroy Dearborn.

Nancy, J.-L. (2008). The inoperative community (P. Connor, Ed.; P. Connor, L. Garbus, M. Holland, \& S. Sawhney, Trans.). Minneapolis, MN: University of Minnesota Press.

Novalis (1798/2007). Notes for a romantic encyclopedia (D. W. Wood, Ed.). Albany, NY: State University of New York Press.

Olaso, E. de. (1988). The two skepticisms of the Savoyard vicar. In R. A. Watson \& J. E. Force (Eds.), The skeptical mode in modern philosophy: Essays in honor of Richard H. Popkin (pp. 43-57). Dordrecht, The Netherlands: Kluwer. https://doi.org/10.1007/978-94-009-2744-5_3

Pahl, K. (2012). Tropes of transport: Hegel and emotion. Evanston, IL: Northwestern University Press. https://doi.org/10.26530/OAPEN_628773

Pascal, R. (1953). The German Sturm und Drang. Manchester, England: Manchester University Press.

Paster, G. K. (2004). Humoring the body: Emotions and the Shakespearean stage. Chicago: University of Chicago Press. https://doi.org/10.7208/chicago/9780226648484.001.0001

Paster, G. K., Rowe, K., \& Floyd-Wilson, M. (Eds.). (2004). Reading the early modern passions: Essays in the cultural history of emotion. Philadelphia: University of Pennsylvania Press.

Plutchik, R. (1962/1991). The emotion: Facts, theories, and a new model (revised ed.). Lanham, MD: University Press of America.

Plutchik, R. (1980). Emotion: A psychoevolutionary synthesis. New York: Harper \& Row.

Porter, R. (2001). The Enlightenment (2nd ed.). New York: Palgrave. https://doi.org/10.1007/978-1-137-09800-9

Pribic, R. (2008). Alienation, irony, and German Romanticism. Crisolenguas, 1(1), 3-10. http://hdl.handle.net/10385/660

Priestly, J. (1775/2013). The history and present state of electricity: With original experiments. Cambridge, UK: Cambridge University Press.

Pyle, F. (1995). The ideology of imagination: Subject and society in the discourse of romanticism. Stanford, CA: Stanford University Press.

Reid, J. (2007/2019). The anti-romantic: Hegel Against ironic romanticism. New York: Bloomsbury.

Ritzer, G. (1999). Enchanting a disenchanted world: Revolutionizing the means of consumption. Thousand Oaks, CA: Pine Forge Press.

Rothbard, M. N. (1995). An Austrian perspective on the history of economic thought (vol. 2). Auburn, AL: Ludwig von Mises Institute.

Rotstein, A. (2018). Myth, mind and religion: The apocalyptic narrative. New York: Peter Lang Publishers. https://doi.org/10.3726/978-1-4539-1828-9

Rousseau, J.-J. (1754/1986). Discourse on the origin and foundation of inequality among men. In J.-J. Rousseau,Discourses and essay on the origin of language (V. Gourvitch, Ed. and Trans.) (pp. 117-237). New York: Harper \& Row.

Rousseau, J.-J. (1762a/1979). Émile: Or, on education (A. Bloom, Trans.). New York: Basic Books.

Rousseau, J.-J. (1762b/1982). The social contract (M. Cranston, Trans.). Harmondsworth, Middlesex, UK: Penguin Books.

Rousseau, J.-J. (1765-1770/1953). The confessions (J. M. Cohen, Trans.). London: Penguin Books.

Rousseau, J.-J. (1781/1986). Discourses and essay on the origin of language (V. Gourevitch, Ed. and Trans.). New York: 
Harper \& Row.

Schiller, F. von (1794/2004). On the aesthetic education of man: In a series of letters (R. Snell, Trans.). Mineola, NY: Dover.

Schlegel, F. (1799/1991). Philosophical fragments (P. Firchow, Trans.). Minneapolis, MN: University of Minnesota Press.

Searle, J. R. (1991). Consciousness, unconsciousness and intentionality. Philosophical Issues, 1, $45-66$. https://doi.org/10.2307/1522923

Sebald, H. (1984). New-age romanticism: The quest for an alternative lifestyle as a force of social change. Humboldt Journal of Social Relations, 11(2), 106-127. http://www.jstor.org/stable/23261838

Seeman, M. (1959). On the meaning of alienation. American Sociological Review, 24(6), 783-791. https://doi.org/10.2307/2088565

Seeman, M. (1991). Sentiments and structures: Strategies for research in alienation. In A. Oldenquist \& M. Rosner (Eds.), Alienation, community, and work (pp. 17-34). New York: Greenwood Press.

Senault, J.-F. (1642/1987). De l'usage des passions. Paris: Fayard.

Shaftesbury, Third Earl of (A. A. Cooper). (1699-1714/2001). An inquiry into virtue and merit. In D. D. Den Uyl (Ed.), Characteristics of men, manners, opinions, times (vol. 2) (pp. 1-100). Indianapolis, IN: Liberty Fund.

Shelly, M. (1818/2012). Frankenstein: The 1818 text, Contexts, criticisms (2nd ed.) (J. P. Hunter, Ed.). New York: W. W. Norton.

Skempton, S. (2010). Alienation after Derrida. New York: Continuum International Publishing Group.

Smith, A. (1759/1976). The theory of moral sentiments. Indianapolis, IN: Liberty Classics. https://doi.org/10.1093/oseo/instance.00042831

Solomon, R. E. (1983). In the spirit of Hegel: A study of G. W. F. Hegel's Phenomenology of Spirit. Oxford, UK: Oxford University Press.

Spinoza, B. de (1677/1957). The ethics of Spinoza (D. D. Runes, Ed.). New York: Citadel Press.

Stambaugh, J. (1986). The real is not the rational. Albany, NY: State University of New York Press.

Steintrager, J. A. (2004). Cruel delight: Enlightenment culture and the inhuman. Bloomington, IN: Indiana University Press.

Stone, A. (2014). Alienation from nature and early German romanticism. Ethical Theory and Moral Practice, 17(1), 41-54. https://doi.org/10.1007/s10677-013-9467-7

Sullivan, J. W. N. (1933/1959). The limitations of science. New York: The Viking Press.

Tarnas, R. (1991). The Passion of the Western mind: Understanding the ideas that have shaped our world view. New York: Harmony Books.

Temkin, O. (1973). Galenism: Rise and decline of a medical philosophy. Ithica, NY: Cornell University Press.

TenHouten, W. D. (2007). A General Theory of Emotions and Social Life. London: Routledge. https://doi.org/10.4324/9780203013441

TenHouten, W. D. (2013). Emotion and Reason: Mind, brain, and the social domains of work and love. London: Routledge.

TenHouten, W. D. (2016). Normless, anomie, and the emotions. Sociological Forum, 31(2), $465-486$. https://doi.org/10.1111/socf.12253

TenHouten, W. D. (2017a). Alienation and Affect. London: Routledge. https://doi.org/10.4324/9781315772479

TenHouten, W. D. (2017b). From primary emotions to the spectrum of affect: An evolutionary neurosociology of the emotions. In A. Ibáñez, L. Sedeño, \& A. M. Garcia (Eds.), Neuroscience and social science: The missing link (pp. 141-167). New York: Springer. https://doi.org/10.1007/978-3-319-68421-5_7

TenHouten, W. D. (2018). From ressentiment to resentment as a tertiary emotion. Review of European Studies, 10(4), 49-61. https://doi.org/10.5539/res.v10n4p49

TenHouten, W. D., \& Kaplan, C. D. (1972). Science and its mirror image: A theory of inquiry. New York: Harper \& Row. 
TenHouten, W. D., Hoppe, K. D., Bogen, J. E., \& Walter, D. O. (1986). Alexithymia; An experimental study of cerebral commissurotomy patients and normal controls. American Journal of Psychiatry, 143(3), 312-316. https://doi.org/10.1176/ajp.143.3.312

Terada, R. (2004). Feeling in theory: Emotion after the death of the subject. Cambridge, MA: Harvard University Press. Tönnies, F. (1887/1957). Community and society (C. P. Loomis, Trans.). New York: Harper \& Row.

Voegelin, E. (1952). The new science of politics: An introduction. Chicago: University of Chicago Press.

Voegelin, E. (1968). Science, politics, and Gnosticism. Chicago: Regnery-Gateway.

Walzel, O. P. (1966). German romanticism (A. E. Lussky, Trans.). New York: Capricorn Books.

Weber, M. (1904-1905/2002). The Protestant ethic and the spirit of capitalism (S. Kalberg, Trans.). Los Angeles: Roxbury Publishing Company.

Weber, M. (1915a/1972). Religious rejections of the world and their directions. In H. H. Gerth \& C. W. Mills (Eds. and Trans.), From Max Weber: Essays in sociology (pp. 323-359). New York: Oxford University Press.

Weber, M. (1915b/1972). The social psychology of the world religions. In H. H. Gerth \& C. W. Mills (Eds. and Trans.), From Max Weber: Essays in sociology (pp. 267-301). New York: Oxford University Press.

Weinberg, I. (2000). The prisoners of despair: Right hemisphere deficiency and suicide. Neuroscience and Biobehavioral Reviews, 24(8), 799-815. https://doi.org/10.1016/S0149-7634(00)00038-5

Wessel, L. P., Jr. (1979). Karl Marx romantic irony and the proletariat: The mythopoetic origins of Marxism. Baton Rouge, LA: Louisiana State University Press.

West, D. (2005). Reason and sexuality in Western thought. Malden, MA: Polity Press.

Wilson, D. J. (1989). Arthur O. Lovejoy and the moral of The Great Chain of Being. Journal of the History of Ideas, 4l(2), 249-265. https://doi.org/10.2307/2709459

Wright, T. (1601/1986). The passions of the mind in general (W. W. Newbold, Ed.). New York: Garland Press.

Žižek, S. (2012). Hegel on marriage. e-flux Journal 34(April). https://www.e-flux.com/journal/34/68365/hegel-on-marriage/

\section{Notes}

Note 1. There were in this period many moral sentimentalisms, which include moral sense theory, espressivism, sensibility theory, dispositionalism, and subjectivism (for an overview, see Kauppinen, 2014; for an in-depth analysis of major figures, see Frazer, 2010).

Note 2. Approval and disapproval, while containing cognitive aspects, have also been interpreted as emotions. Plutchik, $(1962,1980)$, for example, sees 'acceptance' and 'disgust' (rejection) as primary emotional adaptations to the positive and negative experiences of the existential problem of social identity (TenHouten, 2017b).

Note 3. Contemporary researcher Jonathan Haidt's $(2001,2012)$ model of moral judgment shares key features with early sentimentalist theory. He distinguishes two kinds of mental processing. System 1 (fast, intuitive, affective, roughly parallel to Hutcheson's 'senses') and System 2 (slow, effortful, memory-taxing, analytic, reasoning) processing (see Kahneman, 2011), arguing that moral judgments are mostly made using System 1. These judgments are typically experienced as 'gut' reactions based on quick and automatic flashes of affect; if asked to provide reasons for their moral judgments, individuals typically are unable to do so.

Note 4. The young Marx, together with Engels, embraced romanticism, even publishing romantic poems and plays. Marx in 1837 renounced romanticism, yet his vision of a communist utopia was not unlike the romanticists' fantasies of primitive ancient, or medieval experiences of communal wholeness (Wessel, 1979; TenHouten, 2017a, pp. 35-44; 2017b).

Note 5. The cult of sentimentalism came to be regarded as a suspect philosophy, as it contributed to individuals' conspicuously display of insincere emotions, concentrating on their own self-centered pleasure of emotional indulgence to the extent that they became indifferent to the plight of others, so that their displays of affects such as pity were used as a pretext for behavior ranging from indifferent to selfish and cruel (C. Campbell, 1987, p. 174; Bennett, 2015).

Note 6. Despair can be defined as a tertiary emotion, a mixture of the primary emotions sadness, disgust/rejection, and surprise, which combine in pairwise form to also include the secondary emotions loneliness (sadness \& disgust/rejection), shock (disgust/rejection \& surprise), and disappointment (sadness \& surprise) (TenHouten 2017a, pp. 94-99).

Note 7. The romantic philosopher Ludwig Feuerbach (1841) saw in religion an alienation wherein one part of the mind invests in the real world and the other in an imaginary world of spiritual perfection. For Feuerbach, "Alienation involves 
denial of the physical world, in large measure a consequence of religious alienation from sexuality...." Only by refutation of religion's celibacy and its repression of humans as an animal species whose members naturally enjoy physical pleasures, Feuerbach argued, could humans overcome alienation.

Note 8. The poet John Keats (1795-1821) also died of tuberculosis (TB), at age 25, becoming an archetypical case of the wasting away of a romantic consumptive (see his "Ode to a Nightingale"). At this time, in part to mimic the image of the drowned Ophelia in John Millais's Raphaelite painting, fashion-conscious, healthy women starved themselves and chemically lightened their skin to mimic the 'consumptive' look characteristic of TB. The incidence of romantic writers, painters, poets, and composers with TB created a myth that consumption fuels artistic genius, as it was believed that the spes phthisica kind of elation that mixed with depression in pulmonary TB elevates the creative mind (Barrett, 2017). Other romantics believed they could catch glimpses of a lost or future Paradise at the bottom of a bottle (e.g., Edgar Allen Poe) (Bowra, 1961, pp. 174-196).

Note 9. Following Luther, Hegel saw work as the remedium peccati of fallen man, a belief that idleness is unnatural and that labor is the universal basis of society, with the objective of work not upward mobility but taking up the trade or station in life to which one was born. Every kind of work, Luther believed, has an equal spiritual dignity.

\section{Copyrights}

Copyright for this article is retained by the author(s), with first publication rights granted to the journal.

This is an open-access article distributed under the terms and conditions of the Creative Commons Attribution license (http://creativecommons.org/licenses/by/4.0/). 